\title{
Adequate funding: a need for quality assurance in vocational education
}

\author{
Godwin E. Itua \\ Department of Business Education, Federal College of Education, Okene, Nigeria
}

\begin{abstract}
Vocational Education is capital intensive. This is because it is not like any of the liberal academic discipline that has to do with theories rather Vocational Education has to do with skill acquisition and competencies on its beneficiaries. For this to be possible there must be adequate fund to provide facilities, equipment, materials and all the needed prerequisite. Unfortunately, this has not been the case in institutions running Vocational Eeducation. To solve this problem, the writer identified the funding needs of vocational education and went further to discuss the constraints for adequate funding of vocational education. The paper was concluded with suggestions for alternative strategies for adequate funding of Vocational Education to ensure quality assurance. Some of the suggestions among others are that Vocational Education practitioners should convince government to increase allocation or subventions to Vocational Education Institution. Internally generated revenue project should be established via school livestock, crop farms, product manufacturing, bottled water, block moulding, arts works, cloth making, etc. Also staff and students of Home Economics Education should be marketed as caterers and event managers to generate revenue internally to promote Vocational Education. PTA should be involved in the funding of Vocational Education programme.
\end{abstract}

Keywords: Vocation; funding; quality; skill and equipment

\section{INTRODUCTION}

Funding has been the bane of education in Nigeria. According to Ndinechi (1997), the education industry in Nigeria has literally been on the floor since the mid-eighties. The regrettable state of progressive decay of the industry is characterized by actual shortage of funds, equipment as well as prolonged closure of schools as a result of lecturers'/teachers' strikes and students unrest. The funding for vocational education has become difficult even though it is the same form of education that holds the greatest guarantee or key to national development. Because it unlocks the economic potentials of the people; empowers and equips individuals in society to participate in and benefit from their national economy; facilitates economic development and provides the basis for transformation. According to Dike (2009), Vocational Education holds the key to Nigeria's development problems, yet it is the worst applied instrument for national development.

Vocational education has not enjoyed the expected place of prominence it deserves with respect to funding. Vocational Education has always been given the shorter end of the stick when it comes to statutory allocation of funds to the agencies of government. This is evident in Colleges of Education, Polytechnics and Universities where Vocational Education programmes are run. Funding of vocational education programmes should be joint responsibility of the 
Federal, State and Local Governments mother to redeem the nation from high unemployment and rising poverty among the youths. Vocational education, even though is capital intensive, has to be developed since it is the basis for the preparation of individuals to function effectively in the society. To realize the objectives of Vocational Education, adequate fund needs to be provided. It is therefore imperative to examine the funding needs of Vocational Education: Consequences of inadequate funding of vocational education, so as to proffer solution by suggesting alternative means to funding vocational education.

\section{CONCEPTUAL CLARIFICATIONS AND ROLE OF VOCATIONAL EDUCATION}

Vocational education is variously defined by different academics and scholars. For instance, Smith (1991) views Vocational Education as the training that enables one to carry on successfully a socially useful occupation. This definition emphasizes that vocational education as training, is useful for employment in trade and industrial, agricultural, business and home making, among others. Danko (2006) similarly observes that Vocational Education is an education programme that prepares students mainly for occupations requiring manipulative skills or non-technical occupations in fields of agriculture, Business Education, Home Economics, Painting, decorating and others, organized to secure confidence and experience in the individual students. It is also designed to offer training to improve individuals' general proficiency, especially in relation to their present or future occupation. The definition suggests that vocational education emphasis lies on the development of the individual skills that shall be ready to face the challenges of a career after completing formal education training. The vision statement of Federal Government of Nigeria in its National Policy on Education (NPE) (2004) states: (a) provide trained manpower in applied science, technology and business particularly at craft, advanced craft and technical levels; (b) to provide technical knowledge and vocational skills necessary for agricultural, commercial and economic development; (c) to give training and impart the necessary skills to individuals who shall be self-dependent economically. At the tertiary level, graduates are expected to acquire both physical and intellectual skills which will enable them to be self-reliant economically and useful members of the society.

From the foregoing, it can be stated that Vocational Education encompasses the type of education that prepares the learner for entry into employment in his or her chosen career, meets the manpower need of the society, increases the options available to each student, motivating force to enhance all types of learning and enables the learner to wisely choose a career. Vocational Education generally plays important role in reducing unemployment and poverty alleviation.

\section{FUNDING NEEDS OF VOCATIONAL EDUCATION PROGRAMME}

Fund is required in every human endeavour to make it succeed. So also, adequate fund is required in education generally and in Vocational Education in particular to make it successful. Babayi (1998) asserts that funding stands for the source of money gathered, invested or received for a particular purpose. In Nigeria, Schools, Colleges and Universities find it difficult, if not impossible, to implement Vocational Education curriculum (Agricultural Education, Business Education, Home Economics and Fine and Applied Arts) to its fullness due to inadequate fund. In fact, Vocational Education is capital intensive in terms of procurement of equipment, tools, 
laboratory materials/apparatus, as well as manpower training. Inadequate funding is shown in ill-equipped workshops, Home Economics kitchens, farms, typing pools, computer laboratories and shorthand laboratories in the schools:

- Purchase of New Equipment: Vocational Education is skills based and theoretical in nature. Fund is needed to purchase equipment and materials that are needed for proper teaching and learning of Vocational Education. A situation where equipment like tractors, range, pole, computers, photocopiers, typewriters, shorthand laboratories, model office, welding machines, studios, baking oven etc. are not available, teachers and students would not be motivated to learn.

- Regular Maintenance of Equipment: Adequate funds are needed to maintain equipment, machines and facilities to always be in good working condition for proper teaching and learning. There is the need for effective funding to facilitate maintenance and put the equipment in the laboratories in good working conditions through routine checks, servicing and repairs.

- Training and Retraining of Vocational Education Teachers: To ensure quality in Vocational Education, there is need for constant training and retraining of vocational teachers to keep them abreast and updated with modern techniques of teaching and learning. This can be done by making grants available to the teachers to undergo further training, attending conferences, workshops and refresher courses/seminars.

- Funding of Students' Industrial Work Experience Scheme (SIWES): Supervision is a component of Vocational Education programme. The programme is intended to expose the students to real work situation in industries, organizations and institutions where they are most likely to be employed after graduation. In recent times, funds are not made available for teachers of Vocational Education to go and supervise these students. Adequate funds are needed to compensate teachers for the supervision of SIWES so that the intended objectives would be achieved.

\section{CONSEQUENCES OF INADEQUATE FUNDING OF VOCATIONAL EDUCATION}

The NPE (2004) acknowledges that education programmes requires adequate funding for successful implementation. It is also noted that Nigeria as a nation is yet to meet UNESCO's recommendation of minimum of twenty-six percent ( $26 \%$ ) of budgetary allocation to education in it member nations. The above fact has negative consequences not only to education generally but to vocational education in particular. Some of the consequences of inadequate funding of Vocational Education includes but not limited to the following:

- One of the consequences of poor funding is dilapidated infrastructure. According to Boyi (2008) infrastructure in schools today reveals that some schools do not even have a defined workshop nor laboratories where students can practice what they learned. Machines and equipment in our schools are obsolete and poorly maintained that one wonders how these machines are used for proper teaching and learning.

- Another consequence of poor funding is inefficiency and incompetence on the part of graduates of Vocational Education. With poor quality output, neither the beneficiaries nor the society get maximum benefit from the vocational education. Poor funding of Vocational Education programme in our schools, colleges and universities also discourages both teachers and students from developing interest on the course. 
- Poor students' attitude is another consequence of poor funding of Vocational Education programme. SIWES programmes, which were designed to familiarize students/trainees with the world of work, are fast degenerating into a mere formality. Students find it difficult to partake in SIWES due to lack of fund to pay them. Teachers too exhibit poor attitude towards SIWES because they are not well mobilized for SIWES supervisions, other consequences of inadequate funding of Vocational Education have to do with nonimplementation of Vocational Education curriculum to the fullness.

- Due to inadequate funding schools find it difficult to employ adequate number of qualified teachers. Inadequate funding compelled most schools to employ unqualified teachers as alternative to qualified teachers. These caliber of unqualified teachers howl and shout on students or by ridiculing them. These does not augur well for Vocational Education rather it promotes dwindling quality knowledge of our graduates.

- Brain drain is another consequence of inadequate funding of Vocational Education. In the context of this paper, brain-drain refers to the movement of teachers/lecturers of Vocational Education which are needed to impart the vocational skill and knowledge to the students/training from schools, colleges, and universities to industries or to other professional organizations calling for better conditions of service. Some Vocational Education skilled professionals who moved to the industry where they get better pay for their services will not promote quality assurance in Vocational Education.

Generally, consequence of inadequate funding of Vocational Education on the nation will among others include: low level of advancement, low productivity, high level of unemployment, poverty, over-dependence on foreign nations for materials and human resources, high level of crime, political and economic instability, shortage of qualified vocational teachers, insecurity of lives and property, conflicts, loss of national reputation and high level of prostitution.

\section{CONSTRAINTS TO ADEQUATE FUNDING OF VOCATIONAL EDUCATION}

The funding of education in Nigeria is far below standard. The situation is even more critical with the funding of Vocational Education programmes. Some of the reasons for poor funding of vocational education are:

- The sole dependence of Vocational Education institutions on government for all their needs has also contributed to inadequate funding of Vocational Education. In Nigeria, funding Vocational Education for skills has been the responsibility of the State and Federal Governments, educational funding often resulted in poor management, and mismanagement of educational priorities, failure for the government to announce its budget in time, often affects educational activities and implementations.

- Late release of fund/subvention meant for Vocational Education by government. There is no doubt that government often releases funds meant for schools at all levels too late. This statement was supported by Okoro (2005) who opined that there are funding gaps between the budgets submitted by Vocational Education institutions and the amount released to them by government. In fact, the government subventions to these institutions have not kept pace with students' enrolment. Sometimes sources of funding such as revenue, school fees, and subventions fall short of expectation, thereby rendering the Vocational Education plan incapacitated. 
- Corruption/Misappropriation of Funds: In spite of the efforts of the different governments of Nigeria to provide funds for Vocational Education, and the huge amount of money expended, Vocational Education lacks adequate fund to implement various programmes due to high level corruption and misappropriation of funds. Some individuals, especially those in government, are corrupt to the extent that they siphon funds meant for Vocational Education programmes. The consequences of this action results in lack of equipment, facilities, human and non-human materials to the detriment of Vocational Education programmes and this no doubt, affects the quality of the products/graduates.

\section{STRATEGIES FOR ADEQUATE FUNDING FOR QUALITY ASSURANCE IN VOCATIONAL EDUCATION}

Vocational Education is a capital intensive venture since it is the only sure way of bringing development into any nation. It should be properly funded to bring about the realization and achievement of its aim and objectives. The needs of Vocational Education which includes purchase of equipment and materials for teaching, maintenance of equipment, payment of allowances to SIWES supervisors and students, are quite enormous and need to be addressed promptly. Due to all these needs, there is every reason to identify possible strategies or explore alternative means to ensure adequate funding of Vocational Education:

- Establishment of Internally Generated Revenue machine to avoid the sole dependence of Vocational Education Institutions on government for all their needs. The vanishing school livestock and crop farms should be restored and income from there could be ploughed back to ameliorate some of the pressing problems of Vocational Education. Students can be made to engage in product manufacturing for their assessment under the proper guidance and supervision of their teachers. These products could then be sold to the public in a widely publicized open day, in order to generate revenue for the school for the purpose of further promoting Vocational Education. Schools should go into the production of bottled water, block moulding and hiring out to the public, items such as tents, canopies, plastic chairs, plastic tables, plates and spoons. Also, services of the staff and students of Home Economics Education should be marketed as caterers and event managers to generate revenue internally to promote Vocational Education.

- Institutions that run Vocational Education programme should partner with individuals and organizations to ensure increased funding. They can do this by instituting distinguished personality chairs in Vocational Education. As a means of spurring up interest on the part of distinguished guests, some specific structures, laboratories, or farms could be named after such personalities. This would encourage more of such people to finance the building of one Vocational Education facility or the other.

- There should be adequate sensitization of individuals and government to see the usefulness of Vocational Education by Vocational Education practitioners. According to Fafunwa (2010), Nigeria has money but lacks the ability to use it judiciously. Vocational Education holds the major key for the solution of Nigeria's developmental problems. Vocational education practitioner should convince government on the need to increase allocation and subvention to vocational education since it is capital intensive more than other liberal education programmes. It is only by doing this that adequate funds can be realized to ensure quality assurance in Vocational Education. 
- Institutions where Vocational Education is taught should form Parents/Teachers Association (P.T.A.). This association is a body of parents and teachers of a school with the common goal of promoting development in the schools. PTA could raise funds internally among themselves, could also seek external financial assistance from NGOs, corporate organizations (oil companies, communication service providers, financial institutions etc.) and wealthy to execute projects like provision of equipment, facilities and structures in the school to promote Vocational Education.

\section{CONCLUSION}

Vocational education programme cannot achieve its stated objectives as stipulated by the National Policy on Education (NPE) (2004) if it is not properly funded. Vocational Education as a skill development oriented programme is capital intensive as it places a heavy demand on equipment, tools, materials (human and non-human). Teachers of Vocational Education should be adequately remunerated so as to discourage them from joining the industries for better pay. When Vocational Education is properly funded, it will be able to provide functional education; and will equip the beneficiary with needed skills, competencies, attitude and knowledge, that are needed in the nation's drive for technological development.

\section{References}

[1] Babayi, A.U. (1998). Funding of technical education. A paper presented at the First Annual Niger State, Nigeria Association of Teachers of Technology NATT. Held at Secondary Education Board, Minna April.

[2] Danko, A.I. (2006). Entrepreneurship education for vocational and technical education for students - Second edition. Pp. 2-3.

[3] Dike, V.E. (2009). Technical and vocational education: Key to Nigeria's development. Retrieved 26-3-2010 from http:www.triuphnewspapers.com/tech3032009.html.

[4] Fafunwa, H.B. (2010). Classes are bid for failure before examination itself. The Nigerian Education Times, 20-21.

[5] Federal Republic of Nigeria (2004). National policy on education. Lagos: Federal Government Press.

[8] Ndinechi, G.I. (1997). Attaining excellence in teaching inspite of lean resource. In Chidolue, M.L. and Amadi, C. (eds) Effective Teaching: The Nigerian Perspective. Awka: Faculty of Education, Unizik, pp. 300-306.

[9] Okoro, S.K. (2005). Business education and information technology: An imperative for National development. Seminar paper presented at National conference organized by NAFAK $10^{\text {th }}-15^{\text {th }}$ June.

[10] Okpor I. H. N., Mediterranean Journal of Social Sciences 3(4) (2012) 91-94.

[11] Smith, S.J. (1991). Vocational education and the world of word. Boston: Allen and Baco Inc.

[12] Tomáš Hes, Anna Poledňáková, International Letters of Social and Humanistic Sciences 2 (2013) 18-31.

[13] Mohsen Mehrara, Masoumeh zirak, International Letters of Social and Humanistic Sciences 2 (2013) 32-38. 
[14] Taiwo Adewale Muritala, Ismail O. Fasanya, International Letters of Social and Humanistic Sciences 2 (2013) 39-50.

[15] Borowski A., International Letters of Social and Humanistic Sciences 3 (2013) 46-53.

[16] Borowski A., International Letters of Social and Humanistic Sciences 3 (2013) 69-74.

[17] Donovan A. McFarlane, International Letters of Social and Humanistic Sciences 4 (2013) 35-44.

[18] Rajesh K. Yadav, Nishant Dabhade, International Letters of Social and Humanistic Sciences 4 (2013) 49-69.

[19] Borowski A., International Letters of Social and Humanistic Sciences 4 (2013) 70-74.

[20] Paul Bukuluki, International Letters of Social and Humanistic Sciences 5 (2013) 27-44.

[21] Mohsen Mehrara, Maysam Musai, International Letters of Social and Humanistic Sciences 5 (2013) 55-62.

[21] Debiprasad Mukherjee, International Letters of Social and Humanistic Sciences 6 (2013) 41-48.

[22] Tomáš Hes, Alena Neradová, Karel Srnec, International Letters of Social and Humanistic Sciences 7 (2013) 55-75.

[23] Kinga Dziwańska, International Letters of Social and Humanistic Sciences 7 (2013) 96-112.

[24] Borowski A., International Letters of Social and Humanistic Sciences 7 (2013) 113-118.

[25] Mohsen Mehrara, Maysam Musai, International Letters of Social and Humanistic Sciences 8 (2013) 1-7.

[26] Tittenbrun J., International Letters of Social and Humanistic Sciences 11 (2013) 10-34.

[27] Mohsen Mehrara, Hamid Abrishami, Mostafa Boroujli, Mahan Amin, International Letters of Social and Humanistic Sciences 11 (2013) 76-83.

[28] Borowski A., International Letters of Social and Humanistic Sciences 11 (2013) 100-105.

[29] Morteza Amani, Mahmood Goodarzi, Hamze Ahamadian, International Letters of Social and Humanistic Sciences 1 (2014) 7-13.

[30] Seyed Mohammad Marandi, Hossein Pirnajmuddin, International Letters of Social and Humanistic Sciences 1 (2014) 14-27.

[31] Elias Olukorede Wahab, Chioma Joan Ikebudu, International Letters of Social and Humanistic Sciences 1 (2014) 28-42.

[32] Bahram Meihami, Zeinab Varmaghani, Hussein Meihami, International Letters of Social and Humanistic Sciences 1 (2014) 43-5.

[33] Francis Briggs, Elizabeth Desmond, International Letters of Social and Humanistic Sciences 1 (2014) 71-80.

[34] Liverpool E. Onyije, Jacinta A. Opara, International Letters of Social and Humanistic Sciences 1 (2014) 81-87

[35] Sele Sylvester Ebisin, International Letters of Social and Humanistic Sciences 2 (2014) $1-9$.

[36] Tittenbrun J., International Letters of Social and Humanistic Sciences 2 (2014) 20-40.

[37] Borowski A., International Letters of Social and Humanistic Sciences 2 (2014) 110-121.

[38] Pawa Tersoo, International Letters of Social and Humanistic Sciences 3 (2014) 26-36.

[39] Rabi'u Muhammad Ishaq, International Letters of Social and Humanistic Sciences 3 (2014) 37-44.

[40] Adoga James Ada, International Letters of Social and Humanistic Sciences 3 (2014) 45-52. 
[41] Bahram Meihami, Hussein Meihami, International Letters of Social and Humanistic Sciences 3 (2014) 80-91.

[42] Kabiru Ibrahim Yankuzo, International Letters of Social and Humanistic Sciences 4 (2014) 1-8.

[43] Onyike Maggaret Odu, International Letters of Social and Humanistic Sciences 4 (2014) 31-39.

[44] Uloma Charity Oguzor, International Letters of Social and Humanistic Sciences 4 (2014) 97-104.

[45] Okezie A. Ihugba, Alex Odii, A. C. Njoku, International Letters of Social and Humanistic Sciences 5 (2014) 21-34.

[46] Okezie A. Ihugba, Bankoli Bankong, N. C. Ebomuche, International Letters of Social and Humanistic Sciences 5 (2014) 92-113.

[47] Borowski A., International Letters of Social and Humanistic Sciences 6 (2013) 86-90.

[47] Borowski A., International Letters of Social and Humanistic Sciences 3 (2013) 69-74. 